\title{
Preliminary Reflection on Basic Problematics of National Public Infrastructure Financing in Indonesia
}

\author{
Ria Asih Aryani Soemitro ${ }^{1, a)}$ \& Hitapriya Suprayitno ${ }^{2, b)}$ \\ ${ }^{1)}$ Civil Engineering Dept., Institut Teknologi Sepuluh Nopember (ITS), Surabaya, Indonesia. \\ Correspondance : ${ }^{a)}$ ria@ce.its.ac.id \& ${ }^{b}$ suprayitno.hita@gmail.com
}

\begin{abstract}
Furnishing adequate national public infrastructure is an obligation for the government. Financing infrastructure is not an easy problem. The main problem is that the NREB cannot finance the investment cost and the NREB capacity is not enough to finance the whole infrastructure needed. If in general, the public infrastructure is merely a cost, there are certain infrastructure that can generate revenue. Meanwhile, the GDP is far higher than the NREB. So, thinking involving private funds in public infrastructure financing is logical. Thus public infrastructure financing should be a mixture of a public and private fund. The activity involving the Private Sector must be in an Attractive Comercial Activity. Thus preferably for revenue generator infrastructure. Revenue can be generated in various forms. The basic idea of solutions can be grouped into fully financed by public budget, by a mixture of a public-private fund, and by fully privately financed. Each group has its characteristics and derivative solution.
\end{abstract}

Keyword : infrastructure asset management, infrastructure financing

\section{INTRODUCTION}

Indonesia is a very large country, an archipelago, with 13,000 islands. It has an area of 1,916,862.20 sq.km and a population of 265 million persons in the year 2018 (BPS, 2019). Referring to its enormous size and archipelago condition, Indonesia needs an enormous number of different Public Infrastructures, all over the whole area.

The Government of Indonesia has to furnish Indonesia with adequate good infrastructure, as her responsibility. The basic main problem for infrastructure financing is the annual National Revenue Expenditure Budget (NREB), in the Indonesian language is called as APBN (Anggaran Pendapatan dan Belanja Negara), is not enough to finance the Investment Cost. In Indonesia, the NREB capacity is also not enough to finance the whole infrastructure needed. Meanwhile, the Gross Domestic Product (GDP) is far much higher than the annual NREB. Therefore, instead of thinking about how the NREB must be arranged, it is logical to think to involve the Private Fund to participate in the Public Infrastructure development and operation. The Private Fund involvement must be based on the Attractive Commercial Activity (Andreas et al, 2019; Crosetti, 2010; Du et al, 2019; Kepala Bappenas, 2012; Mandasari \& Wahyuni, 2019; Putri \& Wisudanto, 2016; Susantono \& Berawi, 2012; Usubaliev, 2019). This big, vital, and important problem needs to be thought and solved.

Public Infrastructure expenditure in Indonesia, even if it grows from year to the next, but still it should be considered as too low. The Public Infrastructure expenditure, from 2009 to 2013 grew steadily, the value and its percentage to the NREB are presented in Table 1. Share of infrastructure investment in 2013, among different source, was still dominated by the NREB at Rp. 203.9 Trillion, by Regional Revenue and Expenditure Budget (RREB) was at Rp. 95.6 Trillion, by State-Owned Enterprises (SOE) was at Rp. 77.4 Trillion, and by Private Sector was merely at Rp 60.2 Trillion. The share of the Private Sector is still pretty low. Comparing the 
Indonesian expenditure to those of India and China, in terms of the percentage to the NREB, for the year of 2013, can be presented as follows, Indonesia was at 3-4\%, India was at 7-8\%, and China was at $10-11 \%$. Finally, it is important to notice the gap in public infrastructure expenditure to achieve the $7 \%$ of the NREB. For the year 2013, with economic growth of $6.8 \%$ and the GDP at Rp. 9,284 T, the infrastructure expenditure was at Rp. $438.1 \mathrm{~T}$. The gap to achieve the 7\% GDP was Rp. 211.8 T (Bappenas, 2014).

Tabel 1. Infrastructure Expenditure 2009-2013

\begin{tabular}{|c|c|c|}
\hline \multirow{2}{*}{ Year } & $\begin{array}{c}\text { Expenditure } \\
R p . \text { Trillion }\end{array}$ & $\begin{array}{c}\text { Procentage to NREB } \\
\%\end{array}$ \\
\hline 2009 & 91.3 & 1.64 \\
\hline 2010 & 99.4 & 1.53 \\
\hline 2011 & 128.7 & 1.73 \\
\hline 2012 & 174.9 & 2.05 \\
\hline 2013 & 203.9 & 2.30 \\
\hline source : Bappenas, 2014. & \\
\hline
\end{tabular}

Infrastructure Asset Management (IAM) must cover the whole Infrastructure Life Cycle of Infrastructure. Thus, thinking of how to equip the country with enough and good infrastructure needed is part of IAM Topics (Suprayitno \& Soemitro, 2018; Suprayitno \& Soemtro, 2019). Financing Infrastructure is a very big strategic problem for IAM. Therefore, for developing the Knowledge and Science of IAM, this problematic need to be well understood and well solved. A good understanding must be started from a good understanding of the problem itself.

Indonesia experience various method of Public Infrastructure Financing. In principle, it can be divided into three: self-financing by using Public Budget, by using the Loan from International Bank (World Bank (WB), Asian Development Bank (ADB), International Bank for Reconstruction and Development (IBRD), Japan International Cooperation Agency (JICA0, etc), and by Public-Private Partnership (PPP). Each of this three modes has its various derivatives and its various characteristics and problems (Andreas et al, 2019; Andriyani, 2019; Benson \& Sugiana, 2010; Crosetti, 2010; Du et al, 2019; Goh \& Yang, 2019; Maire de Paris, 2018; Mandasari \& Wahyuni, 2019; Putri \& Wisudanto, 2016; Thabib \& Kurniawan, 2018).

This paper presents a preliminary reflection on the main basic problems of national public infrastructure financing. The main objective of the paper is to set a foundation for following researches on Infrastructure Financing.

\section{RESEARCH METHOD}

This research is not experimental. This is rather deductive research to formulate a certain concept. The method used is a deductive reflection based on literature review and knowledge possession. The reflection follows these following steps: basic view of public infrastructure from the point view of IAM, the public infrastructure financial characteristics, the comparison of NREB versus the GDP, the international bank for development, formulation of the basic problem for public infrastructure financing, followed a reflection of the different possibility of financing arrangement forms, and ended by a conclusion.

\section{BASIC PROBLEMATICS OF PUBLIC INFRASTRUCTURE FINANCING}

\section{Basic View of Public Infrastructure for IAM}

Infrastructure is developed to execute a certain function needed by its area of service. The infrastructure must be managed to be able to function sustainably well, economically, 
efficiently, effectively, and must respect the sustainability (green) principle. All pertinent risks must be considered. The public infrastructures must be managed by different governmental levels from the national level, provincial level, down to the city, and regency level. Assignment to different levels depends on the infrastructure function and service area coverage. Each infrastructure has its responsible institution or its managing body (Supratyitno \& Soemitro, 2018; Suprayitno \& Soemitro, 2019).

Public Infrastructure is an infrastructure needed by a region for the well functioning of the region, and it is normally used together by the population. Public Infrastructure is a Public Service Obligation for the government and it must be under government responsibility. In Indonesia, according to the new code of State Treasury, the public infrastructures are owned by the Treasury - Ministry of Finance. Those then lent to the Technical Ministry to be used to execute their functions (UU 1/04). The public infrastructure normally can be used freely. Certain infrastructure can be used only by tariff payment. Therefore generally, the infrastructure has more economic benefit then financial benefit.

Infrastructure experience life cycle phenomenon, started from an idea, planned, designed, constructed, administrated, used, maintained, rehabilitated, developed, removal for certain, and evaluated. Certain infrastructures never experience removal, they are always developed (Suprayitno \& Soemitro, 2019). Some examples of public infrastructure, among others, are public work infrastructures, transportation infrastructures, energy infrastructures, communication infrastructures, etc.

\section{Basic Characteristics of the Public Infrastructure Financial Aspect}

\section{General Characteristics}

Public Infrastructure's financial characteristics mainly concern with the infrastructure cost and revenue, along its life cycle. The cost always exists without or with any revenue. Certain infrastructures can be used by payment only and other infrastructures generate revenue from activities other than its main function.

\section{$\underline{\text { Infrastructure Life Cycle Cost }}$}

Infrastructure Life Cycle Cost is in correlation with the Infrastructure Life Cycle phenomena (PP 27/14). Therefore, the Basic Components of Public Infrastructure Life Cycle Costs consists of investment cost, administration cost, annual operation cost, annual maintenance cost, rehabilitation cost, development cost, removal cost, and annual management cost. The investment cost and the development cost, in general, are very high compared to the others. The rehabilitation cost can very high dependence on the infrastructure damage seriousness (Suprayitno \& Soemitro, 2019). The Infrastructure Cost Components are presented in Table 1 below. 
Table 1. Infrastructure Cost Components

\begin{tabular}{|c|c|c|}
\hline \multicolumn{2}{|l|}{\begin{tabular}{|l|} 
Cost Type \\
\end{tabular}} & Explanation \\
\hline \multirow{3}{*}{ Investment Cost } & Planning Cost & $\begin{array}{l}\text { To finance the Master Plan, Feasibility } \\
\text { Study, Evaluation. }\end{array}$ \\
\hline & Design Cost & $\begin{array}{l}\text { To finance the Pra Design, Detailed } \\
\text { Engineering Design }\end{array}$ \\
\hline & Construction Coat & $\begin{array}{l}\text { To finace, the LARAP (Land } \\
\text { Acquisition and Res ettlement), the } \\
\text { Construction }\end{array}$ \\
\hline \multicolumn{2}{|l|}{ Administration Cost } & $\begin{array}{l}\text { To finance the technical and } \\
\text { adminis trative task. }\end{array}$ \\
\hline \multicolumn{2}{|l|}{ Operation Cost } & $\begin{array}{l}\text { To finance the Annual Daily } \\
\text { Infrastructure Operation }\end{array}$ \\
\hline \multicolumn{2}{|l|}{ Maintenance Cost } & $\begin{array}{l}\text { To finance the Annual Maintenance } \\
\text { Cost }\end{array}$ \\
\hline \multirow[t]{2}{*}{ Rehabilitation Cost } & Design Cost & $\begin{array}{l}\text { To finance in case Infrastructure } \\
\text { Design Rehabilitaion is necessary, } \\
\text { normally due to natural disaster. }\end{array}$ \\
\hline & Construction Cost & $\begin{array}{l}\text { To finance the Rehabilition } \\
\text { Construction }\end{array}$ \\
\hline \multirow{3}{*}{ Development Cost } & Planning Cost & \multirow{3}{*}{ Idem with Investment Cost } \\
\hline & Design Cost & \\
\hline & Construction Cost & \\
\hline \multicolumn{2}{|c|}{ Infrastructure Removal Cost } & $\begin{array}{l}\text { To finance the whole Infrastructure } \\
\text { Removal Cost, if the Removal is } \\
\text { needed. }\end{array}$ \\
\hline \multicolumn{2}{|l|}{ Management Cost } & $\begin{array}{l}\text { To finance day to day Management } \\
\text { Cost of the Managing Body }\end{array}$ \\
\hline
\end{tabular}

This Life Cycle Cost is presented as an illustration in Figure 1 below. It must noted that the Investment Cost and the Development Cost are normally far higher than the Annual Operation, and Annual Maintenance Cost. The Rehabilitation Cost can also be very high, it depends on the seriousness of infrastructure damage.

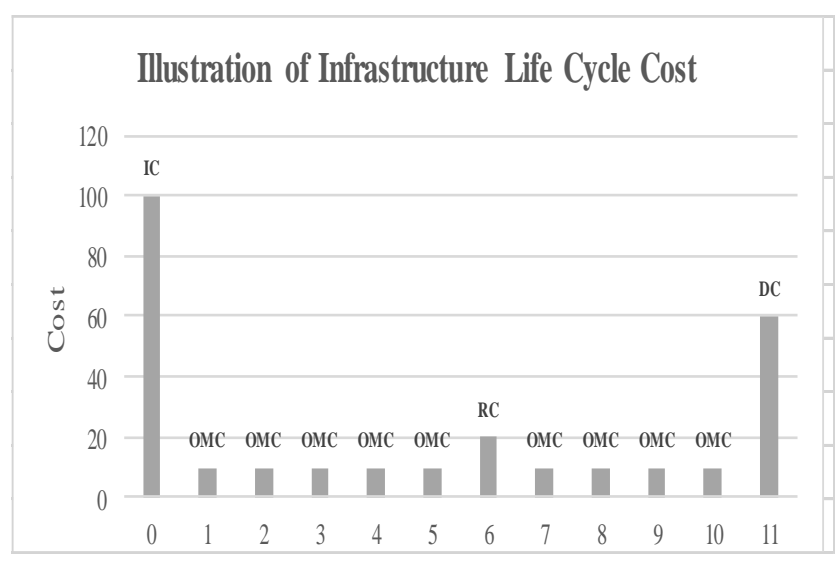

Figure 1. Illustration of Infrastructure Life Cycle Cost.

\section{Public Infrastructure Revenue}

The public infrastructure generally can be used for free. But certain public infrastructure can be used only by paying at a certain tariff of utilization. The others can get revenue from a commercial activity done in its area. There are also certain that can get revenue from bundled 
commercial activity, infrastructure removal, changing of the use, and others (Suprayitno \& Soemitro, 2019). These phenomena are presented in the following Table 2.

Table 2. Basic Variation of Infrastructure Revenue

\begin{tabular}{|c|c|c|}
\hline \multicolumn{2}{|c|}{ Revenue Category } & Explanation \\
\hline \multicolumn{2}{|l|}{ No Revenue } & $\begin{array}{l}\text { Most of the Public Infrastructure has no } \\
\text { revenue. }\end{array}$ \\
\hline \multirow{3}{*}{ Utilis ation Tarrif } & Social Tarrif & $\begin{array}{l}\text { Certain Public Infrats ructure need to instaure } \\
\text { a social tarrif. This tarrif is far below the } \\
\text { totality of infrastructure cost.Example: } \\
\text { irrigation infrastructure for farmer. }\end{array}$ \\
\hline & Partial Tarrif & $\begin{array}{l}\text { Utilis ation Tarrif for certain infrastructure } \\
\text { cover only partial of Infrats ructure Cost. } \\
\text { Example is tariff for bus terminal. }\end{array}$ \\
\hline & Full Tarrif & $\begin{array}{l}\text { Certain Public Infrastructure pos sede a Full } \\
\text { Utilis ation Tarriff, so that all the cost can be } \\
\text { covered by the revenue. Example is toll road. }\end{array}$ \\
\hline \multirow{3}{*}{$\begin{array}{l}\text { Area Utilis ation } \\
\text { Revenue }\end{array}$} & $\begin{array}{l}\text { Needed Annex } \\
\text { Commercial }\end{array}$ & $\begin{array}{l}\text { Certain Infras tructure need annex commercial, } \\
\text { which can be tariffed. Example Trans portation } \\
\text { Terminal. }\end{array}$ \\
\hline & $\begin{array}{l}\text { Unneeded Annex } \\
\text { Commercial }\end{array}$ & $\begin{array}{l}\text { Certain infrastructure may have unneeded } \\
\text { commercial acivity. But the infrastructure area } \\
\text { can be used for commercial activity which can } \\
\text { generate revenue. Example : water tourism in a } \\
\text { dam area. }\end{array}$ \\
\hline & Others & $\begin{array}{l}\text { The area of the infrastructure can be used by } \\
\text { non commercial acvity which can generate } \\
\text { revenue. Example : advertising in road, BTS in } \\
\text { road or dam area, etc. }\end{array}$ \\
\hline \multicolumn{2}{|c|}{ Revenue from Bundling Activity } & $\begin{array}{l}\text { The infrastructural activity is bundled with } \\
\text { commercial activity. Example : Metro in Japan, } \\
\text { Monorail in Kuala Lumpur. }\end{array}$ \\
\hline \multicolumn{2}{|c|}{ Infrastructure Removal Revenue } & $\begin{array}{l}\text { Removal. This activity can generate from } \\
\text { Residual Value and maybe Infrastructure } \\
\text { Swap. }\end{array}$ \\
\hline \multicolumn{2}{|c|}{ Utilization Changing Revenue } & $\begin{array}{l}\text { Certain infrastructures can be no longer } \\
\text { needed to do its function as plan. This } \\
\text { infrastructure can be changed in use to get } \\
\text { revenue. }\end{array}$ \\
\hline
\end{tabular}

\section{Public Budget and Public Infrastructure Cost}

The Public Budget (NREB) available is always not enough to finance the Investment Cost and Development Cost, for huge infrastructure. The budget is generally enough for financing the annual cost, i.e. the administration cost, annual operation, maintenance, management cost. In general, the annual public budget is enough to pay the infrastructure-related installment. This condition is illustrated in Figure 2 below. 


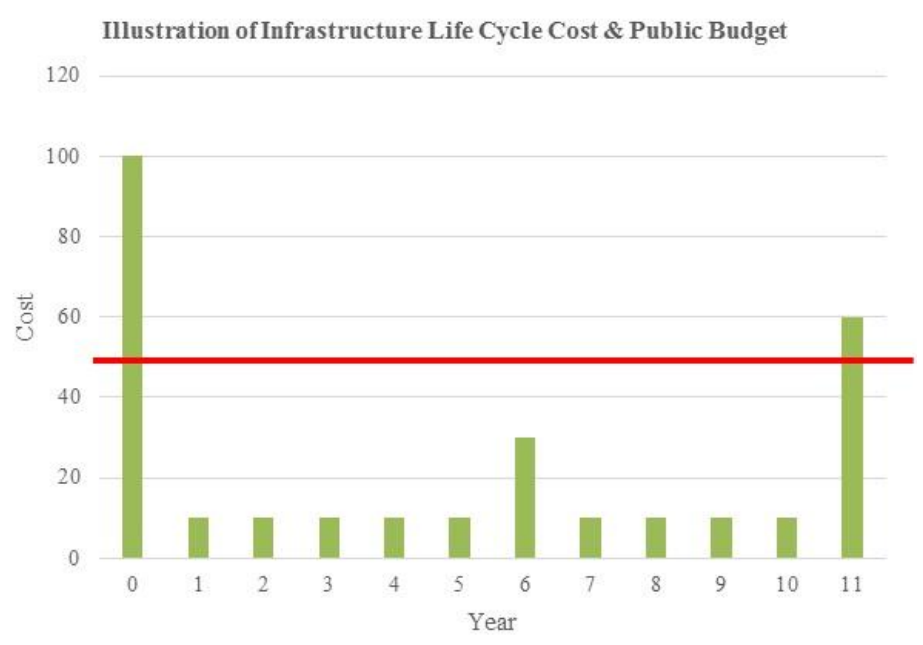

Figure 2. Illustration of Public Infrastructure Cost and Public Budget

\section{NREB and GDP}

In general, for any country in the world, the NREB is far less compared to the Gross Domestic Product (GDP). In Indonesia, in general, the NREB is merely less than $1 \%$ of the GDP (BPS, 2016; BPS, 2019). This leads to the reflection that the Private Sector Financing Capacity is far higher than those of the Public Sector. So, why do not ask the Private Sector to participate in Public Infrastructure Financing? This comparison of GDP and NREB, for Indonesia. is presented in Table 3 below.

Table 3. Comparaison of NREB to the GDP for Indonesia

\begin{tabular}{|l|l|r|r|r|}
\hline Year & $\mathbf{2 0 1 8}$ & $\mathbf{2 0 1 7}$ & $\mathbf{2 0 1 6}$ \\
\hline NREB (Revenue) & $R p$ Billion & $1,894.720$ & $1,750.283$ & $1,882.546$ \\
\hline GDP & $R p$ Billion & $10,425,316.300$ & $9,912,703.600$ & $9,434,613.400$ \\
\hline \% & $\%$ & 0.018 & 0.018 & 0.020 \\
\hline
\end{tabular}

\section{International Financial Institute for Development}

This Annual Public Budget, of the under-developed or developing countries, in general, it is not enough to finance their needs for public infrastructure. The United Nations then, in circa 1950, founded two Financial Institutions, i.e. the World Bank (WB) and the International Monetary Fund (IMF). The main objective is to help the under-developed and developing countries to solve the poverty problem. Later on, other International Financial Development Institution has been established, such as the ADB, the IBRD, the JICA, the AUSAID, the USAID, etc. The underdeveloped and developing countries can use loans offered by these International Financial Institutions (Suprayitno \& Soemitro, 2019).

\section{Basic Problem of the Public Infrastructure Financing}

There are two basic important facts to be considered. Furnishing the country with good and adequate Public Infrastructure is the responsibility of the government. We have two basic main problems, i.e. Public Budget is not enough to finance the Investment Cost and the Development Cost, and Public Budget is not enough to finance the whole Public Infrastructures needed. These two are illustrated in Figure 2 above and Figure 3 below. 


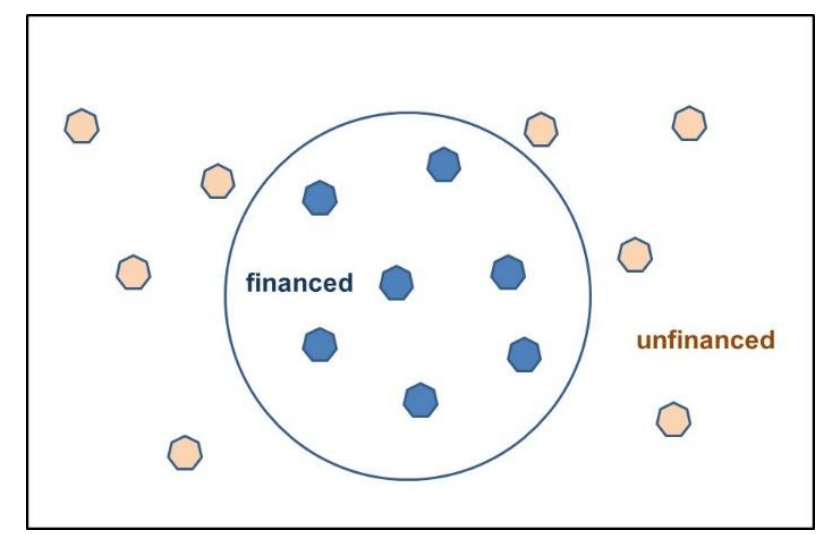

Figure 3. Illustration of Financed and Unfinanced Infrastructures

But certain infrastructure can generate revenue. It has been explained above. The Public Budget is far less compared to the GDP - the whole Private Turn-Over. So why do not think to ask the Private Sector to participate in the Public Infrastructure Financing?

Private Fund can only be used to finance Commercial Activity. So the participation of the Private Fund must be based on Attractive Commercial Activity. The Infrastructure Revenue can vary from Zero Revenue up to Surplus Revenue. So the participation of the Private Sector is reasonable to be thought in several forms. This phenomenon is illustrated in Figure 4 below.

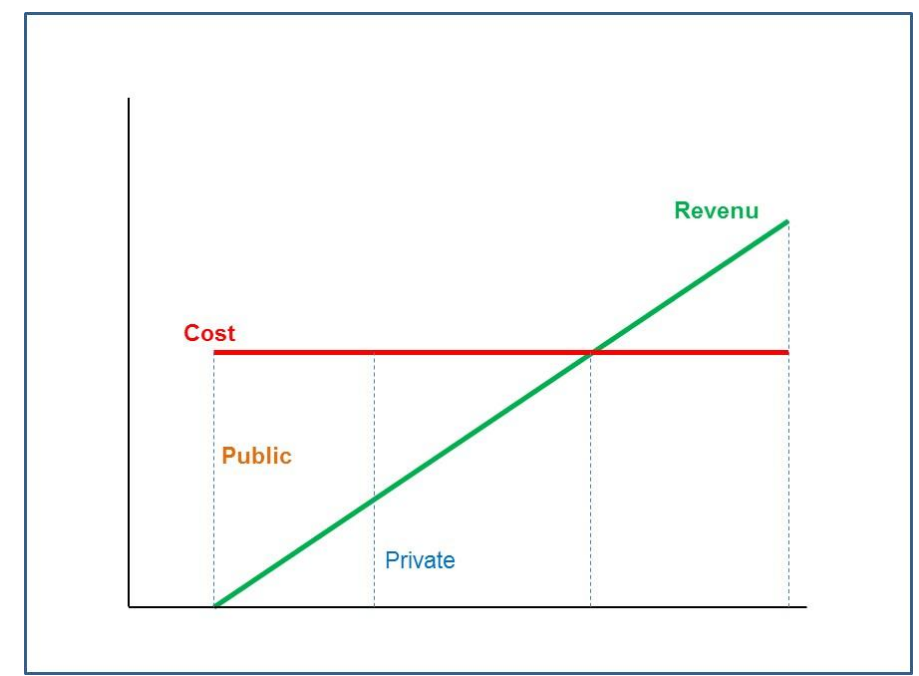

Figure 4. Illustration of Infrastructure Cost and Revenue

Public Infrastructure can be grouped into government responsibility and mix government and private responsibility. Figure 4 above shows us that Private Secor can participate unless the Public Infrastructure has revenue. Since the revenue scale varies from zero up to surplus revenue, the Financing Share between Public Sector and Private Sector is also varying, as shown in Figure 4. The Financing Share between public and private can be illustrated in Table 4 below. 
Table 4. Public Infrastructure Financing Share.

\begin{tabular}{|c|c|c|c|}
\hline \multirow{2}{*}{\multicolumn{2}{|c|}{ Infirastructure Туре }} & \multicolumn{2}{|c|}{ Financing Share } \\
\hline & & \multirow{2}{*}{\begin{tabular}{|l} 
Government \\
Full \\
\end{tabular}} & \multirow{2}{*}{\begin{tabular}{|l|} 
Private \\
Zero \\
\end{tabular}} \\
\hline \multirow{4}{*}{$\begin{array}{l}\text { Government } \\
\text { Owned }\end{array}$} & Non Revenue & & \\
\hline & Social Revenue & Full & Zero \\
\hline & Partial Revenue & Partial & Partial \\
\hline & Surplus Revenu & Zero & Full \\
\hline \multicolumn{2}{|c|}{ Non Government Owned } & Partial & Partial \\
\hline
\end{tabular}

The Financing Share has been illustrated and defined. Now, it is time to think, what kind of activity must be created by the government, as the responsible, for financing Public Infrastructure. It can be based on full governmental activity or a PPP activity. Try to use, at maximum, the Domestic Private Fund, to save the device.

\section{Preliminary Reflection of Different Financing Arrangement Form}

Financing Share has been discussed. Financing Arrangement Forms for each Financial Share should be formulated. Equipped the country with needed Public Infrastructure is a Government Obligation, this included with the Public Financing arrangement. On the other hand, Private Financing is not an obligation and this must be in a form of Feasible Attractive Commercial Activity.

Reflections were made for all Financial Share possibles, from a Full Government Financing up to a Full Private Financing. The various Financing Arrangement Forms are presented in Tabel 5 below.

Tabel 5. Various Possibilities of Financing Arrangement Forms

\begin{tabular}{|c|c|c|c|}
\hline \multicolumn{2}{|l|}{ Revenue Type } & \multicolumn{2}{|c|}{ Financial Arrangement Form } \\
\hline \multirow{2}{*}{\multicolumn{2}{|c|}{ No Revenue }} & \multirow{2}{*}{ Installment } & Bank Loan \\
\hline & & & Infrastructure Purchase \\
\hline \multirow{9}{*}{ Utilis ation Tariff } & \multirow{2}{*}{ Social } & \multirow{2}{*}{ Installment } & Bank Loan \\
\hline & & & Buy Infrastructure \\
\hline & \multirow{3}{*}{ Partial } & \multicolumn{2}{|c|}{ Public Entreprise Infrastructure Management } \\
\hline & & \multirow{2}{*}{$\begin{array}{l}\text { Partial Concession } \\
\text { for Private }\end{array}$} & Operation \& Management \\
\hline & & & \\
\hline & \multirow{4}{*}{ Surplus } & \multicolumn{2}{|c|}{ Public Entrprise Infrastucture Management } \\
\hline & & \multirow{3}{*}{$\begin{array}{l}\text { Full Concession for } \\
\text { Private }\end{array}$} & Public Entreprise \\
\hline & & & Mix Entreprise \\
\hline & & & Private Entreprise \\
\hline \multirow{3}{*}{ Area Utilis ation } & Needed Commerce & \multicolumn{2}{|c|}{ Create Needed Commerce } \\
\hline & UnNeded Commerce & Cretae Commerce & - \\
\hline & Other & Advertis ement & - \\
\hline \multirow{2}{*}{\multicolumn{2}{|c|}{ Bundled Commerce }} & \multirow{2}{*}{ Concession } & Full \\
\hline & & & Partial \\
\hline \multirow{2}{*}{\multicolumn{2}{|c|}{ Infrastructure Removal }} & \multirow{2}{*}{$\begin{array}{l}\text { Infrastructure } \\
\text { Removal }\end{array}$} & Sell to get Residual Value \\
\hline & & & Infrastructure Swap \\
\hline \multirow{3}{*}{\multicolumn{2}{|c|}{ Other Utilization }} & Construction & - \\
\hline & & \multirow{2}{*}{ Concession } & BOT \\
\hline & & & Renue Share \\
\hline \multicolumn{4}{|l|}{ Government Bond } \\
\hline
\end{tabular}


Each Financial Arrangement Form written above is briefly explained as follows. The explanation was presented very briefly.

$\underline{\text { Installment }}$

Installment Financing Mode can be done in two ways. First, borrow the money from the bank and pay the installment after. Second, buy the infrastructure from the private or state-owned enterprise and then pay the installment after.

- Bank Loan: create the Indonesian Infrastructure Financial Institute.

- Infrastructure Purchase: create the Infrastructure Developer Company.

Managing Commercial Public Infrastructure by State-Owned Enterprise

Certain infrastructure can be commercialized by utilization tariffs. The revenue is high enough, at the minimum it can pay the Operation and Maintenance Expenditure. The operation is complicated, especially related to the safety aspect. The role of the infrastructure is strategic for the national economy, The government can create StateOwned Enterprise to manage the Commercial Infrastructure. Example: seaport, ferry port, airport, and railways.

Give Concession to Private Sector (Construction \& Operation)

Certain infrastructure can be given as a concession to Private. The private built and operate the infrastructure for a concession period. The infrastructure is still in government possession. After the period is finished, the operation of the infrastructure will be handed to the government.

- Full Concession (BOT - Built Operate and Transfer)

- Partial Concession (OMC - Operate and Maintenance Concession)

Utilization of Infrastructure Area

Certain Infrastructure Areas can be used for Activity Generating Revenue. The activity can be as Annex Commercial Activity, Connex Commercial Activity, or other Activity.

- Annex Commercial Activity: Commercial Activity needed by the infrastructure. For example, the terminal needs refreshment activity, grocery activity, etc.

- Connex Commercial Activity: certain infrastructure can be used to organize certain Commercial Activities, like a Dam can be used for tourism activity, etc.

- Other Activity can be placed in Infrastructure Area, like Advertisement in the road.

Bundled Commercial Activity

Infrastructure management is blended with full commercial activities. Example: Kuala Lumpur Monorail. The monorail passenger urban transport must be subsidized. The passenger tariff can not cover the whole expenditure. So the KL Monorail Operator is given a Mall Concession to gain Revenue.

Blended Financing

Blended Financing is used for the case when the Public and the Private, each of them cannot work by itself. They have to create a joint venture activity with Blended Financing, in terms of asset, loan, and operation. Example: Jakarta Monorail. The financing is done as a blended between the Public and Private Sectors.

Infrastructure Removal

Certain Infrastructure Removal can generate Revenue. For example, the Removal Steel Bridge can be sold as old steel. Certain infrastructure has Residual Value.

- Residual Value.

- Infrastructure Swap

Changing Utilisation

Certain infrastructure may experience to do its function is no longer needed. Meanwhile the infrastructure still in good condition. So the use of infrastructure can be changed from the form function. The new function can be arranged as an activity that can generate revenue. Several examples of these are the dead railway line can be changed to become a 
commercial kiosk, a former sugar factory has been changed to become a museum and attraction activity.

\section{Government Bond}

The government can issue Infrastructure Bond based on the possession of Public Infrastructure.

Each Financial Arrangement Form has its characteristics. Each solution will be appropriate for different cases.

\section{CONCLUSIONS}

This research on the basic problem of public infrastructure financing has been finished and gave the following main conclusions.

- Furnishing the country with Public Infrastructure is under the responsibility of the government.

- Public Infrastructures are normally can be used for free. But certain Public Infrastructure could generate revenue. This can be gotten in divers forms, i.e. utilization tariff, infrastructure area commercial utilization, bundled commercial activity, and used as a base for issuing government obligation.

- The Infrastructure Life Cycle Cost, in terms of expenditure, is dominated by Investment Cost and Development Cost.

- The NREB is not enough to finance the whole needs of Infrastructure Cost. In general, the Annual NREB value is normally less than $1 \%$ of the GDP. It is normal to ask the Private Sector to finance the public infrastructure.

- The Financial Arrangement Forms to cope with the Infrastructure Financial are various.

This research has induced some curiosities to develop a good understanding of this matter. Among others, these are the Characteristics of Life Cycle Cost for different infrastructure, Types of Private Participation Form, Characteristics of different Financial Arrangments Forms, identification of Infrastructure Connex and Annex Commercial, etc.

Notes. This paper is part of Working Papers to develop the Knowledge and Science of Infrastructure Asset Management in Indonesia.

\section{REFERENCES}

Andreas, A., Rahman, H.Z., Petrocyani, J.S., Perwitasari, D. \& Sejatiguna, P.M. (2019). "Identification of Options for Financing and Management Scheme". Journal of Infrastructure Policy and Management, Vol. 2, No.1, March 2019, pp. : 17-26.

Andriyani (2019). "Analisis Tahap Perencanaan dan Penyiapan Proyek KPBU SPAM Umbulan Provinsi Jawa Timur”. Jurnal Infrastruktur, Vol. 5, No. 2, Desember 2019, Hal. : 69-78.

Benson, Peter \& Sugiana, Kawik (2010). "Shifting The Mind-Set: Public Service Obligations and Pioneer Services in Indonesia's Transport Sectors". Prakarsa, Issue \#3, July 2010, pp. : 3-8.

BPS (2016). Statistik Indonesia 2016. Badan Pusat Statistik. Jakarta.

BPS (2019). Statistik Indonesia 2019. Badan Pusat Statistik. Jakarta.

Crosetti, Mike (2010). "A New Generation of Public-Private Partnership". Prakarsa, Issue \#3, July 2010, pp.: 12-16.

Du, Y., Fang, J., Ke, Y., Philbin, S.P. \& Zhang, J. (2019). "Developing a Revenue Sharing Method for an Operational Transfer-Operate-Transfer Project". Sustainability 2019, 11, 6436.

Goh \& Yang (2009). "Developing a Life-Cycle Costing Analysis Model for Sustainability Enhancement in Road Infrastructure Project". Rethinking Sustainable Development: 
Planning, Infrastructure Engineering, Design, and Managing Urban Infrastructure - 26 March 2009. The Queensland University of Technology. Brisbane.

Bappenas (2014). Alternatif Pembiayaan Infrastruktur. Kementerian Perencanaan Pembangunan Nasional - Badan Perencanaan Pembangunan Nasional. Jakarta.

Maire de Paris (2018). Projet Urbain Maine Montparnasse. Reunion Publique, 21 Septembre 2018.

Mandasari, V. \& Wahyuni, E.T. (2019). "Infrastructure Development by Public-Private Partnership in Indonesia: A Systematic Review". CSID Journal of Infrastructure Development, Vol.2, No. 2, pp: 153-160.

PP 27/14. Peraturan Pemerintah Nomor 27 Tahun 2014 tentang Pengelolaan Barang Milik Negara/Daerah.

Putri, Sefila \& Wisudanto (2016). "Struktur Pembiayaan Pembangunan Infrastruktur di Indonesia Penunjang Pertumbuhan Ekonomi”. Simposium 1 Jaringan Perguruan Tinggi untuk Pembangunan Infrastruktur Indonesi, Surabaya, 2016.

Suprayitno, H. \& Soemitro, R.A.A. (2018). "Preliminary Relexion on Basic Principle of Infrastructure Asset Management". Jurnal Manajemen Aset Infrastruktur \& Fasilitas, Vol.2, No. 1, Maret 2018, Hal. : 1-9.

Suprayitno, H. \& Soemitro, R.A.A. (2019). "Preliminary Reflection on Basic Principle of Public Infrastructure". Jurnal Manajemen Aset Infrastruktur \& Fasilitas, Vol. 3, Suplemen 1, Juni 2019, Hal. : 15-24.

Susantono, Bambang \& Berawi, Muhammed Ali (2012). "Perkembangan Kebijakan Pembiayaan Infrastruktur Transportasi Berbasis Kerjasama Pemerintah Swasta di Indonesia". Jurnal Transportasi, Vol. 12, No. 2, Agustus 2012, Hal. : 93-102.

Thabib, P. \& Kurniawan, F. (2018). "Fungsi Lembaga Penjamin Simpanan dalam Membangun Sistem Perbankan yang Solid demi Kelangsungan Pembangunan Infrastruktur di Indonesia". Jurnal Manajemen Aset Infrastruktur \& Fasilitas, Vol.2, Edisi Khusus, Desember 2018, Hal. : 19-22.

Usubaliev, Ulukbev (2019). Infrastructure Financing in Asian Landlocked Developing Countries: Challenge, Opportunity, and Modalities. Working Papers. ESCAP Economic and Social Commission for Asia and the Pacific. Bangkok.

UU 1/04. Undang-Undang Nomor 1 Tahun 2004 tentang Perbendaharaan Negara. 
(e)ISSN 2656-8896 (p)ISSN 2656-890X

Journal of Infrastructure and Facility Asset Management - Vol. 2, Issue. 1, March 2020 